\title{
Anti-inflammatory duration of action of fluticasone furoate/vilanterol trifenatate in asthma: a cross-over randomised controlled trial
}

George Bardsley ${ }^{1}$, Peter Daley-Yates², Amanda Baines ${ }^{3}$, Rodger Kempsford ${ }^{3}$, Mathew Williams ${ }^{1}$, Tony Mallon ${ }^{1}$ Irene Braithwaite ${ }^{1}$, Kylie Riddell ${ }^{4}$, Shashidhar Joshi ${ }^{5}$, Philippe Bareille ${ }^{3}$, Richard Beasley ${ }^{1}$ and James Fingleton ${ }^{1 *}$ (D) on behalf of the study team

\begin{abstract}
Background: Fluticasone furoate/Vilanterol trifenatate (FF/I) is an inhaled corticosteroid/long-acting beta-agonist combination with a prolonged bronchodilator duration of action. We characterised the time-course of onset and offset of airway anti-inflammatory action of FFNI, as assessed by fraction of exhaled nitric oxide (FeNO), and compared this to the bronchodilator duration of action.

Methods: A single-centre, randomised, double-blind, placebo-controlled, two-period, crossover study was undertaken in 28 steroid-naive adults with asthma. Participants with an $\mathrm{FEV}_{1} \geq 60 \%$ predicted, reversible airway disease, and FeNO $>40$ ppb received FFNI 100/25 mcg or placebo once daily for 14 days. FeNO and peak expiratory flow were measured twice-daily during treatment and during a 21-day washout period. FEV ${ }_{1}$ was measured for five days from treatment cessation. The primary outcome measure was FeNO change from baseline ratio for 21 days following treatment cessation.

Results: In the 27 subjects who completed the study, median (range) baseline FeNO was 87 ppb (42-212). FF/NI $100 / 25$ mcg reduced FeNO by day 3, ratio FFNI versus placebo 0.72 ( $95 \%$ confidence interval $0.61-0.86$ ) with the maximum reduction occurring at day 14, $0.32(0.27-0.37)$. Following cessation of treatment FeNO remained suppressed for 18 days, ratio on day 180.77 (0.59-1.00), whereas improvements in FEV 1 and peak flow were maintained for 3 to 4 days post-treatment.
\end{abstract}

Conclusions: The anti-inflammatory duration of action of FFNI is consistent with the high glucocorticoid receptor affinity and long lung retention of fluticasone furoate. The anti-inflammatory effect of FF/VI was of greater duration than its bronchodilator effect in adults with mild asthma.

Funding GlaxoSmithKline (201499).

Trial registration: Prospectively registered on ClinicalTrials.gov registry number NCT02712047.

Keywords: Asthma, Nitric oxide, Clinical trial

\footnotetext{
* Correspondence: james.fingleton@mrinz.ac.nz

${ }^{1}$ Medical Research Institute of New Zealand, Private Bag 7902, Newtown,

Wellington 6242, New Zealand

Full list of author information is available at the end of the article
}

(c) The Author(s). 2018 Open Access This article is distributed under the terms of the Creative Commons Attribution 4.0 International License (http://creativecommons.org/licenses/by/4.0/), which permits unrestricted use, distribution, and reproduction in any medium, provided you give appropriate credit to the original author(s) and the source, provide a link to the Creative Commons license, and indicate if changes were made. The Creative Commons Public Domain Dedication waiver (http://creativecommons.org/publicdomain/zero/1.0/) applies to the data made available in this article, unless otherwise stated. 


\section{Background}

Combination inhaled corticosteroid (ICS) / long-acting beta-agonist (LABA) therapy forms the cornerstone of guideline recommended management of moderate to severe asthma [1] and in some countries ICS/LABA combination inhalers are the most commonly prescribed ICS containing medication [2]. Most ICS/LABA medications require twice-daily dosing, however adherence to ICS-containing therapy is low and changing inhaled therapy to a once-daily regimen is suggested by international guidelines as a strategy for improving adherence $[1,3]$. These findings have led to the development of ICS and LABA medications with a prolonged duration of action, allowing once-daily dosing.

Fluticasone furoate / Vilanterol trifenatate (FF/VI) $100 / 25 \mathrm{mcg}$ is an ICS/LABA combination licensed for the once-daily treatment of asthma and chronic obstructive pulmonary disease [4]. In people with asthma, after a single dose of FF/VI, bronchodilation was maintained for $72 \mathrm{~h}$ post dose with clinically significant bronchodilation persisting for at least $48 \mathrm{~h}$ [5]. However, the onset and duration of anti-inflammatory action of FF/VI has not been studied and since LABA monotherapy without concomitant ICS therapy is associated with increased mortality in asthma [6], it is important to determine whether the anti-inflammatory duration of action of FF/VI is of at least the same duration as the bronchodilator activity. Although this is of limited relevance for chronic therapy in treatment adherent patients it may be important for patients who miss one or more doses. The primary objective of this study was to characterise the duration of anti-inflammatory activity of FF/VI administered to patients with asthma. We hypothesised that FF would exhibit a prolonged duration of anti-inflammatory action, as the FF component is an ICS with higher glucocorticoid receptor affinity [7] and more prolonged lung retention [8], compared to other ICS.

\section{Methods}

\section{Trial design and participants}

This study was a single-centre, randomised, double-blind, placebo-controlled, two-period, crossover, repeat dose study carried out by the Medical Research Institute of New Zealand (MRINZ) in Wellington, New Zealand.

Eligible participants were aged 18 to 65 inclusive, had a doctor's diagnosis of asthma for at least six-months prior to enrolment, were prescribed a short-acting $\beta 2$-agonist for at least 12 weeks prior to screening, had a fraction of exhaled nitric oxide (FeNO) of greater than $40 \mathrm{ppb}$ at the time of screening, screening pre-bronchodilator forced expiratory volume in one second $\left(\mathrm{FEV}_{1}\right)$ of at least $60 \%$ predicted, (NHANES III reference values) and demonstrated presence of reversible airways disease within the last six months, defined as an increase in FEV1 of at least 12\% from baseline and an absolute change of at least $200 \mathrm{~mL}$ within the $30 \mathrm{~min}$ following inhalation of $400 \mathrm{mcg}$ salbutamol via a valved holding chamber.

Additional inclusion and the exclusion criteria are provided in the online supplement.

Prospective ethics approval was obtained from the Health and Disability Ethics Committees, New Zealand (Reference 16/STH/13). The trial was prospectively registered on the ClinicalTrials.gov registry (NCT02712047). Written informed consent was obtained prior to any study-specific procedures. The trial was performed in accordance with the ethical principles of the Declaration of Helsinki, International Conference on Harmonisation of Good Clinical Practice Guidelines, and applicable regulatory requirements.

\section{Randomisation and blinding}

Participants were randomly assigned to one of two treatment sequences $(\mathrm{AB}$ or $\mathrm{BA}$, where $\mathrm{A}$ is placebo and $\mathrm{B}$ is FF/VI $100 / 25 \mathrm{mcg}$ ) in a $1: 1$ ratio in accordance with the randomization schedule generated prior to the start of the study by the study statistician, using validated GlaxoSmithKline (GSK) internal software. Participants, investigators, and the sponsor were blinded to sequence allocation for the duration of the study.

After randomisation, participants completed a 14-day treatment period, during which participants received inhaled study medication once-daily, followed by a 21-day, short-acting beta-agonist (SABA) only, washout period, before crossing over to the other arm of the study. A period of up to 28 days was permitted between study periods. The study schematic is shown in Fig. 1.

\section{Procedures}

Eligible participants completed a 7 day run-in period prior to randomisation to confirm ability to perform FeNO and peak expiratory flow (PEF) measurements without supervision. Baseline FeNO (Niox Vero, Aerocrine, Sweden) and spirometry (Jaeger Masterscreen, Erich-Jaeger, Germany) measurements were completed in accordance with American Thoracic Society/ European Respiratory Society guidelines.

Patients were admitted into the Clinical Trials Unit at Wellington Hospital for a five day monitoring period, on the first day of which the final administration of study medication was witnessed by investigators. Participants completed twice daily PEF and FeNO measurements throughout the treatment and monitoring periods, as well as $\mathrm{FEV}_{1}$ measurements at each visit and twice daily during the inpatient period. Inpatient morning (AM) $\mathrm{FEV}_{1}$ readings were obtained between 7 am and $10 \mathrm{am}$, with evening (PM) readings $12 \mathrm{~h}$ after the AM reading. Each participant performed inpatient readings at a similar time each day and retained the same Niox Vero and PEF meter for the duration of the study, to minimise test 


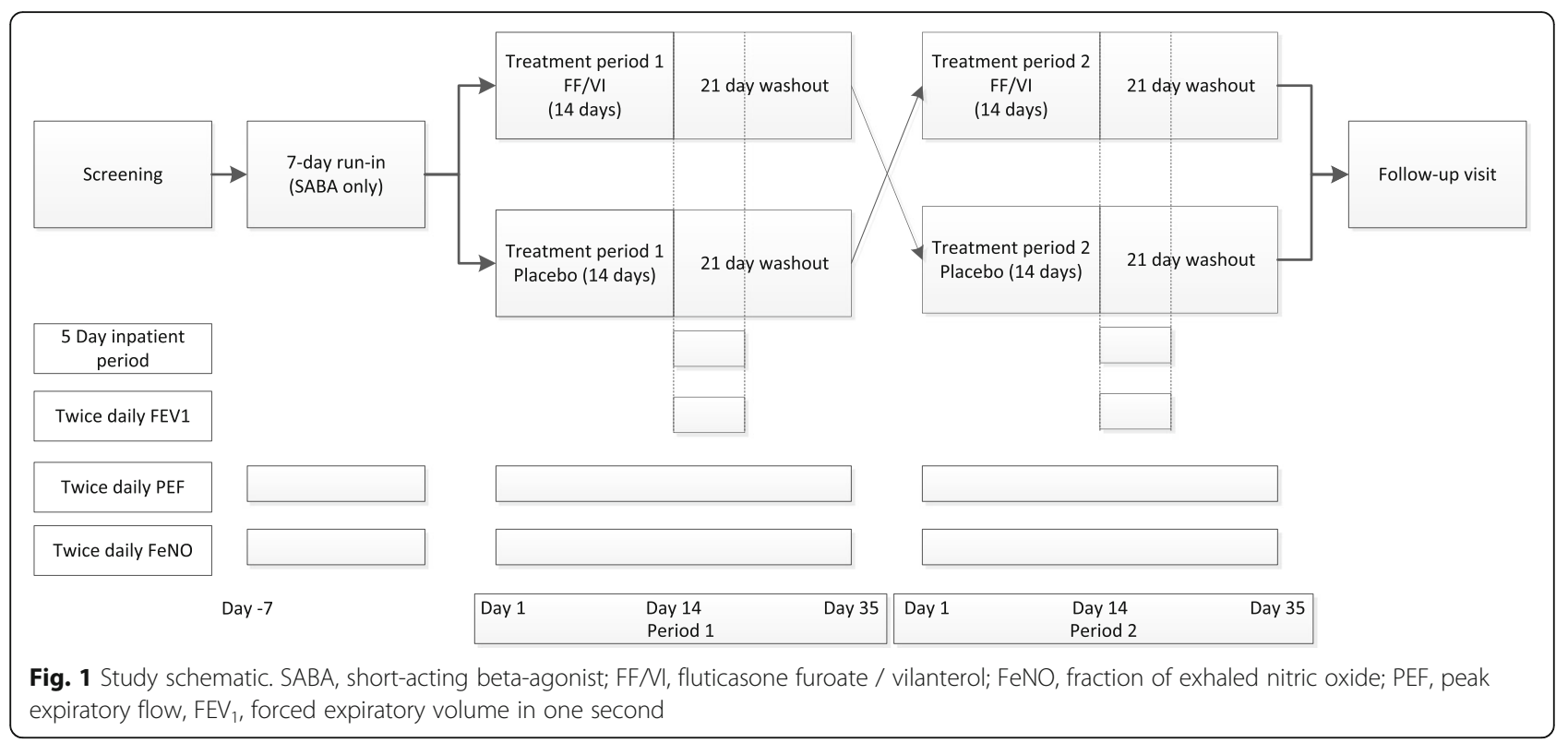

to test variability. Participants avoided nitrate-rich foods for the duration of the study. As forced expiratory manoeuvres may cause short-term alteration in FeNO the measurement sequence was FeNO followed by $\mathrm{FEV}_{1}$ and then PEF, at all time-points. $\mathrm{FEV}_{1}$ and PEF measurements taken within $6 \mathrm{~h}$ of SABA use were not included in the analysis.

Blood eosinophil levels (XE platform, Sysmex Corporation, Japan) and serum periostin levels (see Additional file 1) were determined at baseline, at the end of treatment, and seven and 21 days after cessation of repeat dose treatment, for exploratory analyses. This study also included an exploratory biomarker investigation using serum samples collected at the same time as the blood eosinophil samples. The global metabolomics and lipidomic profiles were measured pre-dose and on days 15 and 21 in each period, and these exploratory analyses will be reported in detail in a separate manuscript.

\section{Outcomes}

The primary end point was change from baseline FeNO over time following the cessation of repeat dose treatment with FF/VI. Pre-specified secondary end points were change from baseline FeNO over the FF/VI treatment period, measurement of PEF during treatment and following cessation of repeat dose treatment with FF/VI, and measurement of $\mathrm{FEV}_{1}$ pre-treatment and twice daily for five days after cessation of repeat dose treatment with $\mathrm{FF} / \mathrm{VI}$, with a final $\mathrm{FEV}_{1}$ reading on day seven.

\section{Statistical analysis}

As a descriptive study, an estimation approach was adopted to address the primary objective. Point estimates and corresponding 95\% confidence intervals (CI) were constructed for the treatment ratio of FF/VI 100/25mcg and placebo. 28 subjects were to be recruited to ensure 24 evaluable subjects. Based upon a within-subject coefficient of variation of $21.6 \%$, estimated from a previous study with a sample size of 24 subjects [9], it was estimated that the lower and upper bounds of the $95 \% \mathrm{CI}$ for the treatment ratio (FF/VI vs Placebo) for FeNO would be approximately $14 \%$ of the point estimate.

Following loge-transformation, the primary end point of FeNO change from baseline ratio following cessation of treatment was analysed using a mixed effects repeated measures model with fixed effect terms for period, treatment, day, time, (period-level baseline)*day"time interaction term, treatment*day*time interaction term, period-level baseline and subject-level baseline. Day"time interaction term was fitted as a repeated measure. FeNO was loge-transformed prior to deriving subject-level baseline and period-level baseline. Point estimates and their associated 95\% CI were constructed for the difference [FF/VI 100/25mcg] - [Placebo] at each time point. The point estimates and their associated 95\% CI were then back-transformed to provide point estimates and $95 \% \mathrm{CI}$ for the ratios, [FF/VI 100/25mcg]/[Placebo], for each time point.

Secondary end points of FeNO change from baseline ratio during treatment and $\mathrm{FEV}_{1}$ were analysed similarly to the primary FeNO endpoint. FEV1 was not log-transformed. PEF, safety data, and biomarker data were summarised descriptively. As serum periostin levels and blood eosinophil levels show significant inter-subject variability, values were normalised to the individual's baseline level and response to treatment was expressed as a percentage change from baseline (FF/VI minus placebo). 


\section{Role of the funding source}

The trial was conceived by the academic investigators and sponsored and funded by GlaxoSmithKline. The protocol, available as part of the online data supplement, was developed in collaboration between the principal academic investigators and employees of the sponsor. The first draft of this manuscript was prepared by the academic investigators without medical writing assistance.

\section{Results}

The study was conducted between April 2016 and February 2017, during which 32 potential participants were screened. Four participants were excluded on the grounds of a screening FeNO $\leq 40 \mathrm{ppb}$ and 28 participants were enrolled. One participant withdrew after screening but prior to taking any study medication. 27 participants successfully completed both study periods and were included in the final analysis (Additional file 1: Figure S1).

Baseline characteristics of the 27 randomised participants are shown in Table 1. Participants had mild to moderate airflow obstruction at baseline, mean (standard deviation) $\mathrm{FEV}_{1}$ percent predicted 87.7 (10.6). Median (range) baseline FeNO and blood eosinophils were $87 \mathrm{ppb}$ (42 to 212 ) and $0.33 \times 10^{\wedge} 9 / \mathrm{L}$ ( 0.18 to 1.18 ) respectively.

The time-course of FeNO during the 14-day treatment and 21-day washout periods is shown in Table 2 and Fig. 2. Summary data by treatment period are provided in Additional file 1: Table S2. Compared with placebo, FF/VI 100/25mcg treatment decreased the FeNO by the third day following onset of treatment, change from

Table 1 Baseline Characteristics of Randomised participants

\begin{tabular}{ll}
\hline Characteristic & Study population $(N=27)$ \\
\hline Age (yrs.) & $24.5(8.1)$ \\
Sex & $10(37 \%)$ \\
$\quad$ Female & $17(63 \%)$ \\
$\quad$ Male & \\
Ethnic Origin & $4(15 \%)$ \\
$\quad$ Māori & $20(74 \%)$ \\
$\quad$ NZ European & $3(11 \%)$ \\
$\quad$ Other & $14(51.9 \%)$ \\
History of allergic rhinitis & $24.6(3.5)$ \\
Body-mass index ${ }^{\mathrm{a}}$ & $87.7(10.6)$ \\
FEV ${ }_{1}$ before bronchodilation $(\%$ predicted) & $443(99)$ \\
Peak Expiratory Flow $(I / m i n)$ & $87(42-212)$ \\
FeNO (ppb) & $0.33(0.18-1.18)$ \\
Blood eosinophil count $(\times 10 \wedge 9 / L)$ & $24(88.9 \%)$ \\
Blood eosinophil count $\geq 0.27 \times 10 \wedge 9 / L$ & $187.5(109.4-442.5)$ \\
Serum Periostin (ng/ml) &
\end{tabular}

Values are given as mean (SD), median (Range), or $\mathrm{n}(\%) .{ }^{\mathrm{a}}$ The body-mass index is the weight in kilograms divided by the square of the height in meters baseline ratio $\mathrm{FF} / \mathrm{VI}$ versus placebo 0.72 (95\% CI 0.61 to 0.86 ). The maximum reduction in FeNO occurred on day 14, change from baseline ratio FF/VI versus placebo 0.32 ( 0.27 to 0.37 ).

Following cessation of FF/VI 100/25mcg treatment the FeNO gradually increased towards the values following placebo, remaining suppressed until approximately day 18, ratio 0.77 (0.59 to 1.00). By inspection of Fig. 2 it can be seen that the rate of onset of FeNO suppression was greater than the rate of offset.

FF/VI 100/25 mcg was associated with significant bronchodilation as measured by $\mathrm{FEV}_{1}$ (Table 3, Fig. 3a), adjusted mean $\mathrm{FEV}_{1}$ change from baseline compared with placebo 0.38 ( 0.28 to 0.48 ), $12 \mathrm{~h}$ after the last dose on day 14. After cessation of FF/VI treatment, $\mathrm{FEV}_{1}$ remained significantly different from placebo until the PM measurement on Day 4. The increase in $\mathrm{FEV}_{1}$ with FF/VI relative to placebo was greater than the minimum perceivable improvement $(0.23 \mathrm{~L})$ [10] until day 3 after cessation of treatment, difference $0.18 \mathrm{~L}(0.08,0.28)$. PEF remained significantly greater than placebo until the AM measurement on Day 4 (Additional file 1: Table S1, Fig. 3b).

Blood eosinophil and serum periostin levels throughout the study are shown in Table 4. Baseline blood eosinophils were $\geq 0.27 \times 10^{\wedge} 9 / \mathrm{L}$ for 24 participants $(88.9 \%)$, but the majority of participants had blood eosinophil levels within the normal range throughout the study. Blood eosinophils were reduced after 14 days treatment with FF/VI 100/25 mcg; percentage change from baseline, FF/VI minus placebo, $(95 \% \mathrm{CI}),-17.9 \%$ ( -33.2 to -2.64$)$. The point estimate for serum periostin level change from baseline was lower after FF/VI treatment, however the confidence interval included zero treatment difference, $-6.3 \%$ ( -18.5 to 5.9$)$.

No serious adverse events were reported during the study. Seventeen (63\%) subjects reported adverse events during the study (Additional file 1: Table S3). The most frequently reported adverse events in the study were viral upper respiratory tract infection (reported by 10 subjects, 37\%); and back pain, musculoskeletal pain, and epistaxis (reported by 2 subjects each, 7\%). Only one adverse event, cough with moderate intensity, was reported as potentially drug related. This resolved prior to cessation of study medication.

\section{Discussion}

In this placebo-controlled study of the time-course of anti-inflammatory activity of FF/VI in asthma, treatment with FF/VI 100/25 mcg for 14 days led to the suppression of FeNO for approximately 18 days after withdrawal of treatment. In contrast, following cessation of FF/VI treatment, significant bronchodilation persisted for three to four days. This indicates that FF/VI exhibits a prolonged anti-inflammatory effect consistent with the high 
Table 2 FeNO change from baseline ratio following onset and cessation of treatment

\begin{tabular}{|c|c|c|c|c|c|c|c|}
\hline \multicolumn{8}{|c|}{ A: FeNO change from baseline and FFNl:placebo ratio following onset of treatment } \\
\hline \multirow[t]{2}{*}{ Day of treatment } & \multirow[t]{2}{*}{ Time point } & \multicolumn{4}{|c|}{ Geometric LSmean } & \multirow[t]{2}{*}{ Ratio (FF/NI vs Placebo) } & \multirow[t]{2}{*}{$95 \% \mathrm{Cl}$ of the Ratio } \\
\hline & & $\mathrm{n}$ & FF/VI 100/25 mcg & $\mathrm{n}$ & Placebo & & \\
\hline 1 & PM & 25 & 0.97 & 26 & 0.90 & 1.09 & $(0.91,1.29)$ \\
\hline \multirow[t]{2}{*}{2} & AM & 27 & 0.91 & 27 & 1.00 & 0.91 & $(0.77,1.07)$ \\
\hline & PM & 27 & 0.81 & 25 & 0.89 & 0.91 & $(0.77,1.08)$ \\
\hline \multirow[t]{2}{*}{3} & AM & 27 & 0.75 & 27 & 0.95 & 0.79 & $(0.67,0.94)$ \\
\hline & PM & 27 & 0.64 & 25 & 0.88 & 0.72 & $(0.61,0.86)$ \\
\hline \multirow[t]{2}{*}{4} & AM & 26 & 0.52 & 27 & 0.90 & 0.58 & $(0.49,0.69)$ \\
\hline & PM & 27 & 0.48 & 27 & 0.89 & 0.54 & $(0.46,0.64)$ \\
\hline \multirow[t]{2}{*}{5} & AM & 27 & 0.46 & 27 & 0.99 & 0.47 & $(0.39,0.55)$ \\
\hline & PM & 26 & 0.45 & 26 & 0.95 & 0.47 & $(0.40,0.56)$ \\
\hline \multirow[t]{2}{*}{6} & AM & 26 & 0.45 & 27 & 0.97 & 0.46 & $(0.39,0.55)$ \\
\hline & PM & 27 & 0.41 & 27 & 0.96 & 0.42 & $(0.36,0.50)$ \\
\hline \multirow[t]{2}{*}{7} & AM & 27 & 0.45 & 26 & 0.96 & 0.47 & $(0.39,0.56)$ \\
\hline & PM & 27 & 0.39 & 27 & 0.88 & 0.45 & $(0.38,0.53)$ \\
\hline \multirow[t]{2}{*}{8} & AM & 27 & 0.40 & 27 & 0.94 & 0.43 & $(0.37,0.51)$ \\
\hline & PM & 27 & 0.37 & 26 & 0.90 & 0.41 & $(0.34,0.48)$ \\
\hline \multirow[t]{2}{*}{9} & AM & 26 & 0.39 & 27 & 0.99 & 0.40 & $(0.33,0.47)$ \\
\hline & PM & 25 & 0.34 & 25 & 0.89 & 0.38 & $(0.32,0.46)$ \\
\hline \multirow[t]{2}{*}{10} & AM & 26 & 0.36 & 26 & 0.93 & 0.39 & $(0.33,0.46)$ \\
\hline & PM & 27 & 0.36 & 26 & 0.90 & 0.40 & $(0.34,0.47)$ \\
\hline \multirow[t]{2}{*}{11} & AM & 27 & 0.33 & 27 & 0.92 & 0.36 & $(0.30,0.42)$ \\
\hline & PM & 27 & 0.31 & 27 & 0.88 & 0.36 & $(0.30,0.42)$ \\
\hline \multirow[t]{2}{*}{12} & AM & 27 & 0.39 & 27 & 0.94 & 0.42 & $(0.35,0.49)$ \\
\hline & PM & 27 & 0.35 & 27 & 0.91 & 0.39 & $(0.33,0.46)$ \\
\hline \multirow[t]{2}{*}{13} & AM & 24 & 0.34 & 25 & 0.99 & 0.35 & $(0.29,0.41)$ \\
\hline & PM & 24 & 0.32 & 25 & 0.94 & 0.34 & $(0.29,0.40)$ \\
\hline \multirow[t]{2}{*}{14} & AM & 23 & 0.38 & 23 & 1.00 & 0.37 & $(0.32,0.44)$ \\
\hline & PM & 23 & 0.32 & 22 & 1.00 & 0.32 & $(0.27,0.37)$ \\
\hline
\end{tabular}

B: FeNO change from baseline and FF/I:placebo ratio following cessation of treatment

Day relative to last dose Time point Geometric LSmean

\begin{tabular}{|c|c|c|c|c|c|}
\hline & & $n$ & FF/Nl 100/25 mcg & $n$ & Placebo \\
\hline \multirow[t]{2}{*}{1} & AM & 27 & 0.38 & 27 & 1.03 \\
\hline & PM & 27 & 0.32 & 27 & 0.98 \\
\hline \multirow[t]{2}{*}{2} & AM & 27 & 0.38 & 27 & 0.99 \\
\hline & PM & 27 & 0.35 & 27 & 0.94 \\
\hline \multirow[t]{2}{*}{3} & AM & 27 & 0.45 & 27 & 0.98 \\
\hline & PM & 27 & 0.42 & 27 & 0.91 \\
\hline \multirow[t]{2}{*}{4} & AM & 27 & 0.55 & 27 & 0.98 \\
\hline & PM & 27 & 0.49 & 27 & 0.85 \\
\hline \multirow[t]{2}{*}{5} & AM & 27 & 0.52 & 27 & 0.83 \\
\hline & PM & 26 & 0.48 & 26 & 0.72 \\
\hline \multirow[t]{2}{*}{6} & AM & 26 & 0.53 & 26 & 0.79 \\
\hline & PM & 26 & 0.48 & 24 & 0.78 \\
\hline
\end{tabular}

Ratio (FF/VI vs Placebo) $\quad 95 \% \mathrm{Cl}$ of the Ratio

$\begin{array}{ll}0.36 & (0.31,0.43) \\ 0.33 & (0.28,0.39) \\ 0.38 & (0.32,0.45) \\ 0.37 & (0.31,0.44) \\ 0.46 & (0.39,0.54) \\ 0.47 & (0.40,0.56) \\ 0.56 & (0.47,0.66) \\ 0.58 & (0.49,0.69) \\ 0.63 & (0.53,0.75) \\ 0.67 & (0.57,0.80) \\ 0.67 & (0.56,0.80) \\ 0.62 & (0.52,0.74)\end{array}$


Table 2 FeNO change from baseline ratio following onset and cessation of treatment (Continued)

\begin{tabular}{|c|c|c|c|c|c|c|c|}
\hline \multirow[t]{2}{*}{7} & AM & 27 & 0.49 & 27 & 0.82 & 0.60 & $(0.51,0.71)$ \\
\hline & PM & 25 & 0.49 & 25 & 0.79 & 0.62 & $(0.52,0.74)$ \\
\hline \multirow[t]{2}{*}{8} & $\mathrm{AM}$ & 27 & 0.56 & 25 & 0.82 & 0.69 & $(0.58,0.81)$ \\
\hline & PM & 26 & 0.56 & 27 & 0.82 & 0.68 & $(0.57,0.80)$ \\
\hline \multirow[t]{2}{*}{9} & $\mathrm{AM}$ & 27 & 0.61 & 27 & 0.92 & 0.66 & $(0.56,0.78)$ \\
\hline & PM & 27 & 0.62 & 27 & 0.91 & 0.68 & $(0.57,0.80)$ \\
\hline \multirow[t]{2}{*}{10} & $\mathrm{AM}$ & 26 & 0.66 & 24 & 1.01 & 0.66 & $(0.55,0.78)$ \\
\hline & PM & 27 & 0.67 & 27 & 0.98 & 0.68 & $(0.58,0.81)$ \\
\hline \multirow[t]{2}{*}{11} & $\mathrm{AM}$ & 26 & 0.77 & 26 & 1.06 & 0.73 & $(0.61,0.86)$ \\
\hline & PM & 27 & 0.74 & 27 & 1.01 & 0.73 & $(0.61,0.86)$ \\
\hline \multirow[t]{2}{*}{12} & $\mathrm{AM}$ & 27 & 0.73 & 27 & 1.01 & 0.72 & $(0.61,0.85)$ \\
\hline & PM & 27 & 0.70 & 27 & 0.99 & 0.71 & $(0.60,0.84)$ \\
\hline \multirow[t]{2}{*}{13} & $\mathrm{AM}$ & 25 & 0.76 & 27 & 1.05 & 0.72 & $(0.61,0.86)$ \\
\hline & PM & 25 & 0.74 & 25 & 0.95 & 0.78 & $(0.66,0.93)$ \\
\hline \multirow[t]{2}{*}{14} & $\mathrm{AM}$ & 27 & 0.79 & 26 & 1.00 & 0.79 & $(0.66,0.93)$ \\
\hline & PM & 26 & 0.63 & 25 & 0.95 & 0.67 & $(0.56,0.79)$ \\
\hline \multirow[t]{2}{*}{15} & $\mathrm{AM}$ & 26 & 0.76 & 26 & 0.97 & 0.79 & $(0.66,0.93)$ \\
\hline & PM & 25 & 0.73 & 25 & 0.92 & 0.79 & $(0.66,0.94)$ \\
\hline \multirow[t]{2}{*}{16} & $\mathrm{AM}$ & 27 & 0.75 & 26 & 1.01 & 0.74 & $(0.62,0.87)$ \\
\hline & PM & 27 & 0.73 & 26 & 1.01 & 0.73 & $(0.61,0.86)$ \\
\hline \multirow[t]{2}{*}{17} & $\mathrm{AM}$ & 26 & 0.79 & 25 & 1.03 & 0.77 & $(0.65,0.91)$ \\
\hline & PM & 16 & 0.79 & 18 & 0.97 & 0.81 & $(0.65,1.01)$ \\
\hline \multirow[t]{2}{*}{18} & $\mathrm{AM}$ & 14 & 0.75 & 17 & 0.98 & 0.77 & $(0.61,0.96)$ \\
\hline & PM & 10 & 0.67 & 14 & 0.87 & 0.77 & $(0.59,1.00)$ \\
\hline \multirow[t]{2}{*}{19} & $\mathrm{AM}$ & 10 & 0.78 & 14 & 0.96 & 0.81 & $(0.63,1.05)$ \\
\hline & PM & 6 & 0.67 & 12 & 0.93 & 0.72 & $(0.52,1.00)$ \\
\hline \multirow[t]{2}{*}{20} & $\mathrm{AM}$ & 6 & 0.77 & 12 & 0.99 & 0.78 & $(0.56,1.09)$ \\
\hline & PM & 5 & 0.72 & 7 & 0.92 & 0.78 & $(0.53,1.14)$ \\
\hline \multirow[t]{2}{*}{21} & $\mathrm{AM}$ & 6 & 0.85 & 7 & 1.00 & 0.85 & $(0.59,1.22)$ \\
\hline & PM & 5 & 0.75 & 7 & 0.99 & 0.75 & $(0.50,1.13)$ \\
\hline
\end{tabular}

Legend: Summary of repeated measures statistical analysis of ratio from baseline exhaled nitric oxide (ppb) data after A) onset and B) cessation of repeat dose of treatment. Decrease in $\mathrm{n}$ value is seen from Day 17 after last dose due to permitted study visit windows

glucocorticoid receptor affinity and long lung retention of fluticasone furoate. The anti-inflammatory activity of FF/VI lasts longer than the bronchodilator effect, and therefore unopposed bronchodilator activity is unlikely to occur with FF/VI, a finding relevant to the scenario where patients omit one or more doses.

There are a number of methodological issues pertinent to the interpretation of the study findings. FeNO was used as the primary measure to monitor the anti-inflammatory activity of FF/VI as it is a validated biomarker of Type 2 inflammation in asthma, highly sensitive to ICS therapy, and, unlike alternative biomakers such as sputum or blood eosinophils or serum periostin, can be repeated twice daily in both a home and inpatient setting [11]. To ensure that the anti-inflammatory activity of FF/VI could be detected using FeNO, a screening FeNO $>40$ ppb was used as an inclusion criterion. A FeNO value above 40 ppb predicts responsiveness to ICS in patients with non-specific airways disease, and is the recommended cut-off denoting a 'high' FeNO in the National Institute for Clinical Excellence (NICE) asthma guidelines [12, 13]. As FeNO is suppressed by ICS treatment and cigarette smoking, participants were required to be steroid naive and not current smokers at baseline. We advised participants to follow a low nitrate diet throughout the study, and strictly ensured this was the case during their inpatient stay. The fall in FeNO in both groups towards the end of the inpatient period may be due to a combination of enforcement of the low nitrate diet and reduced exposure to allergens and environmental pollutants. A 21-day washout 


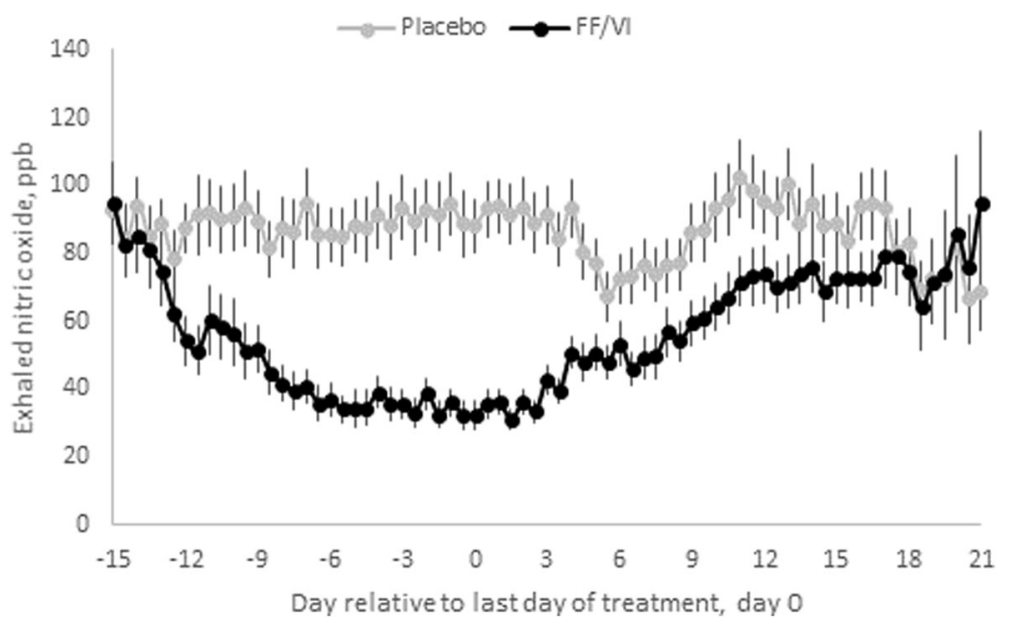

Fig. 2 Time-course of anti-inflammatory activity of FFNI. Mean exhaled nitric oxide (ppb), during treatment and after cessation of treatment, plotted over time, for placebo (grey line) and FFNI (black line). Error bars denote the standard error

period was employed during which time participants were only allowed to take their SABA, with the aim of ensuring that the effect of FF/VI on FeNO had fully resolved. The prolonged time-course of anti-inflammatory activity seen in this study means that for subjects who received FF/VI in period 1 their pre-dose baseline for period 2 was approximately $11 \%$ lower than the period 1 pre-dose value. For subjects who received placebo in period 1 their pre-dose baseline for period 2 was approximately $2 \%$ lower than the period 1 pre-dose value (Additional file 1: Table S2). However, change in FeNO was assessed relative to the pre-dose value at the start of each treatment period, and in the statistical model used to estimate the primary endpoint "period" was included as a term and shown not to be a significant factor, confirming that there was no significant treatment carry-over between periods. Therefore any trend for a lower FeNO value at the start of period 2 was small and not a confounding factor in the study or its conclusions.

Participants were required to demonstrate a minimum $\mathrm{FEV}_{1}$ of at least $60 \%$ predicted as a safety criterion, and at least $12 \%$ bronchodilator reversibility at baseline in order to confirm the diagnosis of asthma. The requirement for a steroid naïve population who were able to tolerate ICS treatment being withheld for up to 21 days required us to recruit only participants with mild asthma. This, in addition to the exclusion of smokers and patients with FeNO levels $<40 \mathrm{ppb}$, mean that these

Table $3 \mathrm{FEV}_{1}$ change from baseline and FFNI vs placebo treatment difference following cessation of treatment

\begin{tabular}{|c|c|c|c|c|c|c|c|}
\hline \multirow{2}{*}{$\begin{array}{l}\text { Day relative } \\
\text { to last dose }\end{array}$} & \multirow{2}{*}{$\begin{array}{l}\text { Time } \\
\text { point }\end{array}$} & \multicolumn{4}{|c|}{ Adjusted Mean FEV } & \multirow{2}{*}{$\begin{array}{l}\text { Difference } \\
\text { (FF/NI vs Placebo) }\end{array}$} & \multirow{2}{*}{$\begin{array}{l}95 \% \mathrm{Cl} \text { of } \\
\text { the difference }\end{array}$} \\
\hline & & $n$ & FF/NI 100/25 mcg & $n$ & Placebo & & \\
\hline \multirow[t]{2}{*}{0} & AM & 27 & 0.44 & 27 & 0.18 & 0.26 & $(0.16,0.36)$ \\
\hline & PM & 27 & 0.44 & 27 & 0.07 & 0.38 & $(0.28,0.48)$ \\
\hline \multirow[t]{2}{*}{1} & AM & 27 & 0.38 & 27 & 0.02 & 0.36 & $(0.26,0.46)$ \\
\hline & PM & 27 & 0.41 & 27 & 0.15 & 0.26 & $(0.16,0.36)$ \\
\hline \multirow[t]{2}{*}{2} & AM & 27 & 0.37 & 27 & 0.03 & 0.34 & $(0.24,0.44)$ \\
\hline & PM & 27 & 0.41 & 27 & 0.16 & 0.24 & $(0.14,0.34)$ \\
\hline \multirow[t]{2}{*}{3} & AM & 27 & 0.31 & 27 & 0.05 & 0.26 & $(0.16,0.36)$ \\
\hline & PM & 27 & 0.36 & 27 & 0.18 & 0.18 & $(0.08,0.28)$ \\
\hline \multirow[t]{2}{*}{4} & AM & 27 & 0.29 & 27 & 0.05 & 0.24 & $(0.14,0.34)$ \\
\hline & PM & 27 & 0.34 & 26 & 0.18 & 0.17 & $(0.07,0.27)$ \\
\hline 5 & AM & 27 & 0.24 & 26 & 0.17 & 0.07 & $(-0.03,0.17)$ \\
\hline $7^{\mathrm{a}}$ & AM & 27 & 0.13 & 24 & 0.09 & 0.04 & $(-0.06,0.14)$ \\
\hline $21^{\mathrm{a}}$ & AM & 27 & 0.06 & 27 & 0.03 & 0.03 & $(-0.07,0.13)$ \\
\hline
\end{tabular}



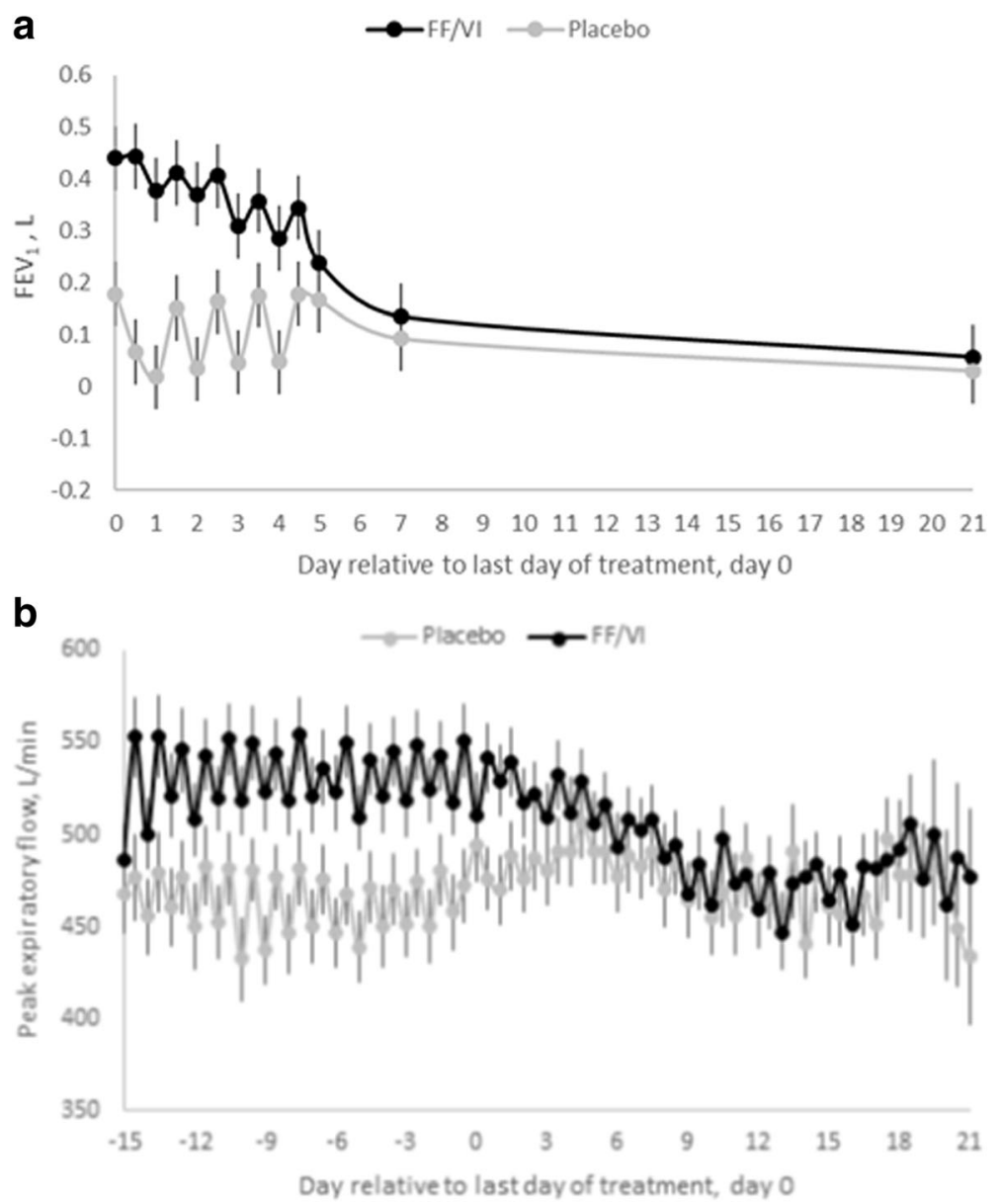

Fig. 3 Time-course of bronchodilator activity of FFNI. a: FEV 1 change from baseline. $\mathbf{b}$ : PEF. Mean (a) FEV $\mathrm{F}_{1}(\mathrm{~L})$ after cessation of treatment and (b) Peak expiratory flow (L/min), during treatment and after cessation of treatment, plotted over time, for placebo (grey line) and FF/VI (black line). Error bars denote the standard error

results may not be generalizable to a wider asthmatic population. Participants were required to remain as inpatients for five days after cessation of treatment to ensure that their environment was as tightly controlled as possible, to avoid exposures that may influence FeNO or lung function measurements. This also allowed us to measure $\mathrm{FEV}_{1}$, which is a more sensitive measure of airflow obstruction than PEF and is a recommended core outcome measure in clinical trials [14].

It was not possible to determine the relative contributions of FF and VI to the anti-inflammatory and bronchodilator actions of combination FF/VI. However, based on

Table 4 Blood eosinophil and serum periostin levels throughout the study, by intervention

\begin{tabular}{|c|c|c|c|c|c|c|}
\hline \multirow[t]{2}{*}{ Day } & \multicolumn{3}{|c|}{ Eosinophils $\times 10 \wedge 9 / \mathrm{L}$} & \multicolumn{3}{|l|}{ Periostin $\mathrm{ng} / \mathrm{ml}$} \\
\hline & $\begin{array}{l}\text { FFNI Median } \\
\text { (min,max) }\end{array}$ & $\begin{array}{l}\text { Placebo Median } \\
\text { (min,max) }\end{array}$ & $\begin{array}{l}\text { Point estimate of } \\
\text { change from baseline } \\
\text { (FFNl - placebo) }\end{array}$ & $\begin{array}{l}\text { FFNI Median } \\
\text { (min,max) }\end{array}$ & $\begin{array}{l}\text { Placebo Median } \\
\text { (min,max) }\end{array}$ & $\begin{array}{l}\text { Point estimate of } \\
\text { change from baseline } \\
\text { (FF/VI - placebo) }\end{array}$ \\
\hline Pre-dose & $0.35(0.20,1.07)$ & $0.34(0.18,1.18)$ & - & $\begin{array}{l}191.10 \\
(109.40,442.50)\end{array}$ & $\begin{array}{l}189.10 \\
(99.40,398.60)\end{array}$ & - \\
\hline $\begin{array}{l}\text { After } 14 \text { days of } \\
\text { treatment (day 15) }\end{array}$ & $0.30(0.18,0.86)$ & $0.38(0.17,0.99)$ & $-0.06(-0.14,0.02)$ & $\begin{array}{l}150.00 \\
(84.10,823.40)\end{array}$ & $\begin{array}{l}171.10 \\
(87.80,386.40)\end{array}$ & $-3.56(-44.36,37.24)$ \\
\hline $\begin{array}{l}\text { Seven days after cessation } \\
\text { of treatment (day 21) }\end{array}$ & $0.30(0.04,0.85)$ & $0.29(0.13,0.70)$ & $-0.02(-0.1,0.08)$ & $\begin{array}{l}173.50 \\
(94.90,471.00)\end{array}$ & $\begin{array}{l}175.70 \\
(102.10,389.90)\end{array}$ & $-8.86(-30.66,12.94)$ \\
\hline $\begin{array}{l}21 \text { days after cessation of } \\
\text { treatment (Day 35) }\end{array}$ & $0.36(0.17,0.87)$ & $0.40(0.21,1.09)$ & $-0.04(-0.12,0.06)$ & $\begin{array}{l}171.70 \\
(100.80,457.70)\end{array}$ & $\begin{array}{l}185.90 \\
(113.30,359.60)\end{array}$ & $-5.34(-30.16,19.46)$ \\
\hline
\end{tabular}


the known properties of FF and VI demonstrated in the clinical trial program that lead to the registration of FF/VI [15], and previous reports that short-acting beta-agonists and LABAs do not affect FeNO [16, 17], the anti-inflammatory activity is likely to be due to the FF component.

FF/VI reduced FeNO within three days of the onset of treatment, with a progressive reduction to about one third of the baseline value by day 14 . This is similar to the time-course of onset of FeNO suppression previously reported for inhaled budesonide, fluticasone propionate (FP), ciclesonide, and combination extra fine beclomethasone dipropionate/formoterol [18-21]. In contrast the suppression of FeNO persisted for 18 days after cessation of FF/VI treatment, which is appreciably longer than that observed with other ICS. Following treatment with budesonide (100mcg or $400 \mathrm{mcg}$ once-daily) [20] for three weeks, the FeNO returned to baseline levels by the end of a one week washout period. Following two weeks of treatment with beclomethasone diproprionate (200mcg/day) the FeNO returned to baseline within one to two weeks in the majority of participants [22]. Similarly, following FP (500mcg twice-daily) [19] the FeNO returned to baseline after two weeks, although no earlier time point measurements were included.

In addition to the changes seen with FeNO, two weeks of treatment with FF/VI reduced the blood eosinophil count by $17 \%$. This finding is in keeping with the limited data available on the effect of ICS on blood eosinophils. In two separate studies in people with moderate asthma, two weeks of FP / salmeterol $100 \mathrm{mcg} / 50 \mathrm{mcg}$ twice daily [23] and six weeks of budesonide $800 \mathrm{mcg}$ per day [24] were associated with reductions in blood eosinophils of 23 and 26\% respectively. The reduction in blood eosinophils with ICS treatment is likely to be associated with a reduction in sputum eosinophils, as blood eosinophils are very strongly correlated with sputum eosinophils [23]. Blood eosinophil levels, although within the normal range for the majority of participants, were $\geq 0.27 \times 10^{\wedge} 9 / \mathrm{L}$ at baseline for 24 (88.9\%). This threshold has previously been shown to have a $78 \%$ sensitivity and $91 \%$ specificity for sputum eosinophilia in participants with mild to moderate asthma [25], so both baseline FeNO and blood eosinophil data are consistent with participants in this study having eosinophilic airway inflammation at baseline. Periostin is associated with a type 2 pattern of inflammation [26], the sensitivity and specificity of the assay used in this study for the prediction of airway eosinophilia has not yet been determined. The point estimate of a $6 \%$ fall in periostin is in keeping with prior published data, with 5 and $12 \%$ reductions in periostin reported with FP 400mcg daily [27] and budesonide $800 \mathrm{mcg}$ daily [28] respectively.

It is difficult to compare the FeNO findings with other ICS as different equivalent daily doses were investigated, which confounds the assessment of responsiveness, as both the onset and offset of ICS-induced reduction in FeNO may be dose dependent [20, 29-31]. In addition, the baseline $\mathrm{FeNO}$ is a determinant of the magnitude and speed of ICS response [20], and the pre-treatment FeNO levels and sampling methodologies were markedly different between studies, with a range of between $6.9 \mathrm{ppb}$ [19] and $122 \mathrm{ppb}$ [32], compared with the baseline value of $87 \mathrm{ppb}$ observed in this study. It is notable that for FF the offset of FeNO suppression was slower than the onset of action. This differs from the pattern previously reported with budesonide where, although the rate of onset and offset of action differed between the $100 \mathrm{mcg}$ and $400 \mathrm{mcg}$ doses, the rates of onset and offset were similar at each dose [20].

The ICS/LABA combination product studied in this investigation contains two molecules that both contribute to its long duration of action. Compared to other ICS, fluticasone furoate exhibits higher binding affinity and a longer duration of occupancy of the ligand binding domain of the glucocorticoid receptor [7]. The structural features of the FF molecule also confer physicochemical properties that result in higher affinity for respiratory tissue and longer lung retention compared to other ICS. Through in vitro and in vivo studies, FF has been demonstrated to have a longer intracellular duration of action than FP [33], as well as higher potency [33], prolonged intracellular retention [7] and prolonged lung absorption kinetics $[7,8]$. Vilanterol has a high $\beta_{2}$ receptor affinity, with rapid onset of action and relatively slow dissociation [34]. The prolonged bronchodilator action of vilanterol may be due primarily to it being a highly lipophilic molecule, leading to the formation of 'depots' in the cell membrane resulting in persistence and reassertion at the $\beta_{2}$-receptor [34].

This prolonged anti-inflammatory effect of FF/VI may have implications for poorly adherent patients as it confirms that the anti-inflammatory activity works alongside the bronchodilator activity for the approved once-daily dosing regimen, and also suggests that patients who miss one or more doses of FF/VI will still receive both anti-inflammatory and bronchodilator coverage for some time after the last dose. Finally, it provides reassurance that they will not be exposed to unopposed LABA activity as they are likely to still derive benefits from its anti-inflammatory effect. However, dosing less frequently than once a day has not been studied and FF/VI is only licensed for use as a once-daily medication.

\section{Conclusions}

Among adult patients with asthma who were not taking ICS at baseline, treatment with FF/VI at a dose of $100 / 25 \mathrm{mcg}$ once daily for 14 days substantially reduced airway inflammation, as measured by FeNO suppression. 
After cessation of treatment, FeNO suppression persisted for approximately 18 days, whereas clinically significant bronchodilation persisted for three to four days. These results show that the duration of anti-inflammatory action of FF/VI is longer than has previously been reported for other ICS studied and exceeds the duration of bronchodilation. Therefore, even when adherence to therapy is poor, there is prolonged anti-inflammatory activity and no unopposed LABA activity with this combination ICS/LABA.

\section{Additional file}

Additional file 1: Supplementary appendix: The anti-inflammatory duration of action of fluticasone furoate/vilanterol trifenitate in asthma. (DOCX $97 \mathrm{~kb}$ )

\section{Abbreviations}

FeNO: Fraction of exhaled nitric oxide; FF: Fluticasone furoate; ICS: Inhaled corticosteroids; LABA: Long-acting beta-agonists; VI: Vilanterol

\section{Acknowledgements}

The Medical Research Institute of New Zealand would like to acknowledge Capital and Coast District Health Board for providing access to the Clinical Trials Unit at Wellington Hospital. No medical writing assistance was received in the production of this manuscript.

\section{Funding}

This research was sponsored and funded by GlaxoSmithKline (201499). The Medical Research Institute of New Zealand is supported by the Health Research Council of New Zealand with Independent Research Organization funding.

\section{Availability of data and materials}

Within 6 months of this publication, anonymized individual participant data, the annotated case report form, protocol, reporting and analysis plan, data set specifications, raw dataset, analysis-ready dataset, and clinical study report will be available for research proposals approved by an independent review committee. Proposals should be submitted to www.clinicalstudydatarequest.com. A data access agreement will be required.

\section{Authors' contributions}

RB conceived the study and wrote the protocol with $G B, I B$, JF, and MW, in collaboration with $A B, R K$ and SJ. Study conduct and data collection was performed by GB, JF, MW, and TM. The first draft of the manuscript was written by JF and RB. Analysis and data interpretation was performed by, GB, JF, KR, RB, PD-Y, PJB, and SJ. All authors contributed to the revision, and approved the final version, of the submitted manuscript.

\section{Ethics approval and consent to participate}

Prospective ethics approval was obtained from the Health and Disability Ethics Committees, New Zealand (Reference 16/STH/13).

\section{Consent for publication}

Not applicable.

\section{Competing interests}

GB, MW and TM have no conflicts of interest to declare. IB has conducted research funded by GSK, Astra-Zeneca and Fisher \& Paykel. JF has received support to attend educational meetings from AstraZeneca, Boehringer-Ingelheim, GSK, and Novartis, has conducted research funded by GSK, Astra-Zeneca and Fisher \& Paykel, and has received honoraria for speaking from AstraZeneca, Boehringer-Ingelheim and Novartis. RB has participated in advisory boards for AstraZeneca, GlaxoSmithKline and Novartis; received research grants from AstraZeneca, Cephalon, Fisher \& Paykel, Genentech, GlaxoSmithKline, Novartis and Sanofi Aventis, and received payment for lectures or support to attend meetings from AstraZeneca and GlaxoSmithKline AB, RK, PB and PDY are GSK employees and hold GSK shares. KR and SJ are GSK employees.

\section{Publisher's Note}

Springer Nature remains neutral with regard to jurisdictional claims in published maps and institutional affiliations.

\section{Author details}

${ }^{1}$ Medical Research Institute of New Zealand, Private Bag 7902, Newtown, Wellington 6242, New Zealand. 'Respiratory Clinical Development, GlaxoSmithKline Research and Development, Stockley Park, Uxbridge, UK ${ }^{3}$ Medicines Development Centre, GlaxoSmithKline Research and Development, Stevenage, UK. ${ }^{4}$ GlaxoSmithKline Research and Development, 82 Hughes Ave, Ermington, NSW 2115, Australia. ${ }^{5}$ Quantitative sciences, GlaxoSmithKline, Bangalore, India.

Received: 26 April 2018 Accepted: 27 June 2018

Published online: 13 July 2018

\section{References}

1. Global initiative for Asthma. Global Strategy for Asthma Management and Prevention [Internet]. [cited 2018 Jul 6]. Available from: https:/ginasthma.org/ 2018-gina-reportglobal-strategy-for-asthma-management-and-prevention/.

2. Reddel HK, Beckert L, Moran A, Ingham T, Ampon RD, Peters MJ, et al. Is higher population-level use of ICS/LABA combination associated with better asthma outcomes? Cross-sectional surveys of nationally representative populations in New Zealand and Australia. Respirology [Internet]. John Wiley \& Sons, Ltd; 2017 [cited 2017 Oct 29];22:1570-8. Available from: http:// doi.wiley.com/10.1111/resp.13123

3. British Thoracic Society, Scottish Intercollegiate Guidelines Network. British guideline on the management of asthma [Internet]. 2016. Available from: https://www.brit-thoracic.org.uk/document-library/clinical-information/ asthma/btssign-asthma-guideline-2016/

4. Relvar Ellipta 92 micrograms/22 micrograms inhalation powder, pre-dispensed Summary of Product Characteristics (SPC) - (eMC) [Internet]. [cited 2017 Nov 5]. Available from: https://www.medicines.org.uk/emc/medicine/28496

5. Braithwaite I, Williams M, Power S, Pilcher J, Weatherall M, Baines A, et al. Randomised, double-blind, placebo-controlled, cross-over single dose study of the bronchodilator duration of action of combination fluticasone furoate/ vilanterol inhaler in adult asthma. Respir Med [Internet]. Elsevier Ltd; 2016; 119:115-21. Available from: https://doi.org/10.1016/j.rmed.2016.09.006

6. Beasley $\mathrm{R}$, Perrin $\mathrm{K}$, Weatherall $M$, Wijesinghe M. Call for withdrawal of LABA single-therapy inhaler in asthma. Lancet [Internet]. 2010 [cited 2017 Nov 5]; 376:750-1. Available from: http://www.thelancet.com/journals/lancet/article/ PIIS0140-6736(10)61158-0/abstract.

7. Salter M, Biggadike K, Matthews JL, West MR, Haase MV, Farrow SN, et al. Pharmacological properties of the enhanced-affinity glucocorticoid fluticasone furoate in vitro and in an in vivo model of respiratory inflammatory disease. Am J Physiol Lung Cell Mol Physiol. 2007;293:L660-L667.

8. Allen A, Bareille PJ, Rousell VM. Fluticasone Furoate, a Novel Inhaled Corticosteroid, Demonstrates Prolonged Lung Absorption Kinetics in Man Compared with Inhaled Fluticasone Propionate. Clin Pharmacokinet [Internet]. 2013 [cited 2017 Sep 1];52:37-42. Available from: https://dx.doi.org/10. 1007\%2Fs40262-012-0021-x.

9. GlaxoSmithKline. Document Number GM2003/00418/00. Study Number FFA10028. A randomized, double-blind, placebo-controlled, balanced incomplete block, multiple dose crossover study to investigate the effect of 3 days repeat dosing of GW685698X (250 and $1000 \mu \mathrm{g})$ and fluticaso [Internet]. Available from: https://www.gsk-clinicalstudyregister.com/files2/ gsk-ffa10028-clinical-study-report-redact.pdf

10. Santanello NC, Zhang J, Seidenberg B, Reiss TF, Barber BL. What are minima important changes for asthma measures in a clinical trial? Eur Respir J [Internet] 1999:14:23-7. Available from: http://erj.ersjournals.com/content/14/1/23.long.

11. Dweik RA, Boggs PB, Erzurum SC, Irvin CG, Leigh MW, Lundberg JO, et al. An official ATS clinical practice guideline: interpretation of exhaled nitric oxide levels (FeNO) for clinical applications. Am J Respir Crit Care Med [Internet]. 2011 [cited 2013 Mar 24];184:602-15. Available from: https:/doi.org/10.1164/ rccm.9120-11ST.

12. Price DB, Buhl R, Chan A, Freeman D, Gardener E, Godley C, et al. Fractional exhaled nitric oxide as a predictor of response to inhaled corticosteroids in patients with non-specific respiratory symptoms and insignificant 
bronchodilator reversibility: a randomised controlled trial. Lancet Respir Med [Internet]. 2017 [cited 2017 Nov 5];0. Available from: http://www.thelancet. com/journals/lanres/article/PIIS2213-2600(17)30424-1/abstract.

13. National Clinical Guideline Centre. Asthma: diagnosis and monitoring of asthma in adults, children and young people [Internet]. Available from: https://www.nice.org.uk/quidance/NG80/.

14. Tepper RS, Wise RS, Covar R, Irvin CG, Kercsmar CM, Kraft M, et al. Asthma outcomes: pulmonary Physiology J Allergy Clin Immunol [Internet]. 2012; 129:S65-87. Available from: https://doi.org/10.1016/j.jaci.2011.12.986.

15. Albertson T, Bullick S, Schivo M, Sutter M. Spotlight on fluticasone furoate/ vilanterol trifenatate for the once-daily treatment of asthma: design, development and place in therapy. Drug Des Devel Ther [Internet] 2016; Volume 10:4047-4060. Available from: https:/www.dovepress.com/ spotlight-on-fluticasone-furoatevilanterol-trifenatate-for-the-once-da-peerreviewed-article-DDDT

16. Yates DH, Kharitonov SA, Barnes PJ. Effect of short- and long-acting inhaled beta2-agonists on exhaled nitric oxide in asthmatic patients. Eur Respir J [Internet]. 1997 [cited 2017 Nov 9];10:1483-8. Available from: http://erj. ersjournals.com/content/10/7/1483

17. Aziz I, Wilson AM, Lipworth BJ. Effects of once-daily formoterol and budesonide given alone or in combination on surrogate inflammatory markers asthmatic adults. Chest [Internet]. The American College of Chest Physicians; 2000; 118:1049-58. Available from: https://doi.org/10.1378/chest.118.4.1049

18. Erin EM, Zacharasiewicz AS, Nicholson GC, Tan AJ, Neighbour H, Engelstätter $R$, et al. Rapid effect of inhaled ciclesonide in asthma: a randomized, placebo-controlled study. CHEST J [Internet]. 2008;134:740-745. Available from: http://journal.chestnet.org/article/S0012-3692(08)60303-7/pdf.

19. van Rensen ELJ, Straathof K, Veselic-Charvat M, Zwinderman A, Bel E, Sterk $P$. Effect of inhaled steroids on airway hyperresponsiveness, sputum eosinophils, and exhaled nitric oxide levels in patients with asthma. Thorax [Internet]. 1999 [cited 2017 Oct 20];54:403-8. Available from: https://www. ncbi.nlm.nih.gov/pmc/articles/PMC1763792/

20. Kharitonov SA, Donnelly LE, Montuschi P, Corradi M, Collins JV, Barnes PJ. Dose-dependent onset and cessation of action of inhaled budesonide on exhaled nitric oxide and symptoms in mild asthma. Thorax [Internet]. 2002; 57:889-896. Available from: https://thorax.bmj.com/content/57/10/889.

21. O'Connor BJ, Collarini S, Poli G, Brindicci C, Spinola M, Acerbi D, et al. Rapid effects of extrafine beclomethasone dipropionate/formoterol fixed combination inhaler on airway inflammation and bronchoconstriction in asthma: a randomised controlled trial. BMC Pulm Med [Internet]. 2011;11:60. Available from: http:/bmcpulmmed.biomedcentral.com/articles/10.1186/1471-2466-11-60.

22. Silkoff PE, McClean P, Spino M, Erlich LA, Slutsky AS, Zamel N. Dose-response relationship and reproducibility of the fall in exhaled nitric oxide after inhaled beclomethasone dipropionate therapy in asthma patients. Chest. 2001;119:1322-8.

23. Lipworth B, Jabbal S, Manoharan A, Anderson W, Short P. Inhaled corticosteroid dose-response on blood eosinophils in asthma. Lancet Respir Med [Internet]. Elsevier; 2016 [cited 2018 Mar 2];4:e1. Available from: https://doi.org/10.1016/ S2213-2600(15)00504-4.

24. Laviolette M, Ferland C, Trepanier L, Rocheleau H, Dakhama A, Boulet LP. Effects of inhaled steroids on blood eosinophils in moderate asthma. Ann N Y Acad Sci [Internet] 1994;725:288-297. Available from: https://doi.org/10. 1111/j.1749-6632.1994.tb39812.x.

25. Wagener AH, De Nijs SB, Lutter R, Sousa AR, Weersink EJM, Bel EH, et al. External validation of blood eosinophils, FENO and serum periostin as surrogates for sputum eosinophils in asthma. Thorax. 2015;70:115-20.

26. Jia G, Erickson RW, Choy DF, et al. Periostin is a systemic biomarker of eosinophilic airway inflammation in asthmatic patients. J Allergy Clin Immunol [Internet] 2012 [cited 2013 May 24];130(3):647-654.e10. Available from: https://doi.org/10.1016/j.jaci.2012.06.025

27. Matsumoto H. Serum Periostin: a novel biomarker for asthma management. Allergol Int [internet]. Elsevier Masson SAS; 2014;63:153-160. Available from: https://doi.org/10.2332/allergolint.13-RAl-0678.

28. Fingleton J, Braithwaite I, Travers J, Bowles D, Strik R, Siebers R, et al. Serum periostin in obstructive airways disease. Eur Respir J [Internet]. European Respiratory Society; 2016 [cited 2016 Jun 10];47:927-934. Available from: https://doi.org/10.1183/13993003.01384-2015.

29. Jatakanon A, Kharitonov S, Lim S, Barnes PJ. Effect of differing doses of inhaled budesonide on markers of airway inflammation in patients with mild asthma. Thorax [Internet]. 1999 [cited 2017 May 26];54:108-14. Available from: http://dx.doi.org/10.1136/thx.54.2.108.
30. Jones SL, Herbison P, Cowan JO, Flannery EM, Hancox RJ, McLachlan CR, et al. Exhaled $\mathrm{NO}$ and assessment of anti-inflammatory effects of inhaled steroid: dose-response relationship. Eur Respir J. 2002;20:601-8.

31. Nolte H, Pavord I, Backer V, Spector S, Shekar T, Gates D, et al. Dosedependent anti-inflammatory effect of inhaled mometasone furoate/ formoterol in subjects with asthma. Respir Med [Internet]. Elsevier Ltd; 2013; 107:656-64. Available from: https://doi.org/10.1016/j.rmed.2013.02.010

32. Kharitonov SA, Yates DH, Chung KF, Barnes PJ. Changes in the dose of inhaled steroid affect exhaled nitric oxide levels in asthmatic patients. Eur Respir J. 1996;9:196-201.

33. Rossios C, To Y, To M, Ito M, Barnes PJ, Adcock IM, et al. Long-acting fluticasone furoate has a superior pharmacological profile to fluticasone propionate in human respiratory cells. Eur J Pharmacol [Internet]. Elsevier B.V.: 2011;670:244-51. Available from: https://doi.org/10.1016/j.ejphar.2011.08.022

34. Slack RJ, Barrett VJ, Morrison VS, Sturton RG, Emmons AJ, Ford AJ, et al. In vitro Pharmacological Characterization of Vilanterol, a Novel Long-Acting 2-Adrenoceptor Agonist with 24-Hour Duration of Action. J Pharmacol Exp Ther [Internet]. 2013;344:218-230. Available from: https://doi.org/10.1124/ jpet.112.198481.

\section{Ready to submit your research? Choose BMC and benefit from:}

- fast, convenient online submission

- thorough peer review by experienced researchers in your field

- rapid publication on acceptance

- support for research data, including large and complex data types

- gold Open Access which fosters wider collaboration and increased citations

- maximum visibility for your research: over $100 \mathrm{M}$ website views per year

At BMC, research is always in progress.

Learn more biomedcentral.com/submissions 